\title{
TITIK TEMU PEMIKIRAN MAHMOUD MOHAMED THAHA DAN ABDULLAHI AHMED AN-NA'IM
}

\author{
Tholkhatul Khoir \\ Universitas Islam Negeri (UIN) Walisongo Semarang Jawa Tengah \\ E-mail: tholkhatul_khoir@walisongo.ac.id
}

\begin{abstract}
Abdullahi Ahmed an-Na'im is deeply influenced by the Islamic Reform Movement in Sudan pioneered by Mahmoud Mohamed Taha. Together with other Taha supporters, an-Na'im formed a sociopolitical community that became famous for Tahaism. This article wants to show how the relationship of the two minds is so close and how Islamic legal thought of an-Na'im is partially influenced by Taha. In terms of historical research methodology, it can be said that Taha is a history of idea for an-Na'im. This is because the thought of an$\mathrm{Na}$ 'im turns out to be the same as Taha in terms of the importance of the naskh, and differs in worship, mysticism, socialism, and public reason. Moreover, the underlying power of the theorem an-Na'im is not merely an individual, not of individual processes aware of its importance in the flow of thought, but rather of the collective goals of a group that underlie individual thought. Most of his thoughts cannot be properly understood as long as their relation to life or to the social implications of human life are not taken into account.
\end{abstract}

Keywords: Mysticism; Naskh; Socialism; Worship

\begin{abstract}
ABSTRAK
Abdullahi Ahmed an-Na'im sangat terpengaruh oleh Gerakan Reformasi Islam di Sudan yang dipelopori oleh Mahmoud Mohamed Taha. Bersama sama dengan para pendukung Taha lainnya, an-Na'im membentuk sebuah komunitas sosial politik yang kemudian terkenal dengan Tahaisme. Artikel ini ingin menunjukkan betapa hubungan pemikiran keduanya sangat dekat dan betapa pemikiran hukum Islam an-Na'im sebagiannya dipengaruhi oleh Taha. Dalam istilah metodologi penelitian sejarah, dapat dikatakan bahwa Taha adalah history of idea bagi an-Na im. Hal ini karena
\end{abstract}


pemikiran an-Na'im ternyata sama dengan Taha dalam hal pentingnya naskh, dan berbeda dalam hal ibadah, tasawwuf, sosialisme, dan public reason. Selain itu, kekuatan yang mendasari sikap teoritis an-Na im bukan semata merupakan sesuatu yang individual semata, yakni tidak berasal dari proses individu menyadari kepentingannya dalam arus pemikiran, akan tetapi lebih berasal dari tujuan-tujuan kolektif suatu kelompok yang mendasari pemikiran individu. Sebagian besar pemikirannya tidak dapat dimengerti secara tepat selama kaitannya dengan kehidupan atau dengan implikasi sosial kehidupan manusia tidak diperhitungkan.

Kata Kunci: Ibadah; Naskh; Sosialisme; Tasawwuf

\section{A. Pendahuluan}

Gerakan pemikiran Islam sejak kemunculannya pertama kali abad 19, hingga akhir abad dua puluh ini masih terus berlanjut. Semangat gerakan ini, memiliki benang merahnya pada upaya pembebasan umat Islam dari kemandekan intelektual sejak lima abad terakhir. Belenggu inilah yang dianggap sebagai sebab utama ketakberdayaan bangsa-bangsa muslim di depan bangsa asing (kolonialisme). Hanya dengan membangun kembali (rekonstruksi) cara pandang dan sikap keberagamaan mereka, kondisi menyedihkan itu dapat diperbaiki. Demikianlah setidaknya yang menjadi penggerak bagi para pemikir Muslim bermunculan dengan berbagai sudut pandangnya, baik sudut pandang liberalisme, rekonstruksi, dekonstruksi, dan sudut pandang-sudut pandang lainnya.

Diantara tokoh-tokoh pemikir Muslim liberal yang muncul di abad dua puluh ini adalah Mahmud Muhamad Thoha dan Abdullah an-Naem. Dua tokoh pemikir Muslim yang memiliki hubungan erat, yakni guru dan murid. Meskipun, Mahmud Muhammad Thoha dapat dikatakan sebagai history of idea bagi Abdullah an-Naem, akan tetapi dari beberapa aspek keduanya memiliki perbedaan-perbedaan yang mendasar.

Pemikiran keagamaan Mahmud Muhamad Thoha berangkat dari tesis membedakan agama dengan syariah. Syari'ah menurutnya hanya satu cara untuk memasuki agama, dan merupakan cara terendah atau batas minimal agama. Pandangan ini diserap oleh muridnya Abdullahi Ahmed An-Na'im . Sejalan dengan Mahmûd, An-Na'im menyatakan bahwa syariah bukanlah Islam itu sendiri melainkan hanyalah interpretasi terhadap teks (nash) yang dipahami melalui konteks historis tertentu . 
Sementara kerangka pikir Abdullah an-Naim, selain meneruskan gagasangagasan gurunya, Mahmud Muhammad Thoha, lebih menitik beratkan pada pemahaman dokonstruksi pemikiran. Maka dalam hal ini, Abdullah an-Naim lebih menekankan pada pembaruan pemahaman hokum Islam.

Berangkat dari latar belakang di atas, tulisan ini akan mengkaji sisi-sisi pemikiran Mahmud Muhamad Thoha dan an-Naim. Pemikiran pertama sebagai induknya, pemikiran kedua sebagai hal sesuatu yang lahir dari induknya. Bagai induk dan anaknya selain memiliki kemiripan, terdapat juga perbedaannya. Dalam mengkaji kedua pemikir tersebut dugunakan analisis deskriptif, yakni menjelaskan dan menggali aspekaspek dalamm dari kedua pemikir tersebut.

\section{B. Pembahasan}

\section{Sosok Mahmoud Mohamed Taha}

Mahmoud Mohamed Țaha, (1909 - 18 Januari 1985) adalah seorang pemikir Sudan, pemimpin, figur politik, theolog, dan insinyur. Ia berperan penting dalam perjuangan kemerdekaan Sudan. Ia adalah pendiri Sudanese Republican Party. Bersama rakyat ia juga mendirikan Republican Botherhood pada bulan Oktober 1945. Ia mempunyai ide revolusioner tentang pesan kedua Islam (the second message of Islam) yang menyebabkannya dieksekusi gantung oleh presiden Sudan waktu itu, Ja ' far Numayri, dengan alasan murtad (http://en.wikipedia.org,2014).

Sebelumnya, ia pernah dipenjara pemerintah kolonial Inggris, yang karenanya ia kemudian mempunyai pemahaman baru tentang Islam yang ia publikasikan dalam beberapa buku di bawah ini:

1. The Middle East Problem (Mushkilät al-Sharq al-Awsaț)

2. This is my Path (Qul Hädhihi Sabili)

3. Mohamed's Path (Tầiq Muhammad)

4. The Message of Prayer (Risālah al-Ṣalāh)

5. The Challenge Facing the Arabs (al-Tahăaddi al-ladhi Yu'aghih al'Arab)

6. Second Message of Islam (al-Risālah al-Thäniyah min al-Islām)

Mahmoud Mohamed Taha dilahirkan pada tahun 1909 di Rufáa, Sudan. Menyelesaikan sekolahnya di Enginering School of Gordon Memorial 
College (kemudian berubah menjadi University of Karthoum, tempat an-Na'im menyelesaikan studi S1-nya di Fakultas Hukum, pada tahun 1936. Sempat bekerja sebagai pegawai negeri sipil di Sudan Railways. Kepeduliannya terhadap penderitaan masyarakat Sudan, saat itu di bawah penjajahan Inggris yang menempatkan wilayah Sudan ke dalam pemerintahan bonekanya di Mesir, mendorong TTaha bergabung ke dalam gerakan kemerdekaan Sudan pada akhir tahun 1930an. Hal inilah yang mendorongnya untuk melepaskan statusnya sebagai seorang pegawai negeri sipil pada tahun 1940 dan merintis usahanya di bidang teknik (Khalid Duran, 1992: 453-467).

Țaha amat kecewa dengan sedikitnya jumlah mahasiswa dan para ilmuwan, yang bergabung dan berjuang demi membebaskan rakyat Sudan. Țaha lahir dari keluarga sederhana, tumbuh dan berkembang pasca era Mahdi yang dibentuk oleh penjajah Inggris, dan dididik dalam sebuah lingkungan persaingan antara kelompok islamis, sekularis, dan marxis (Minlib Dallh, 2009: 417-422).

Sebagai seorang partisipan aktif dalam perjuangan kaum nasionalis memperoleh kemerdekaan pada akhir tahun 1930-an, ia tidak puas dengan sikap para elit terdidik dalam perjuangan itu. Ia mengkritik mereka karena menyerahkan keahliannya kepada pemimpin agama tradisional sektarian yang memperoleh dukungan masyarakat luas dalam keseluruhan negara itu. Partai yang ada juga tidak menerimanya, mungkin karena partai dimaksud diawasi oleh pemerintah kolonial termasuk dalam hal kompromi tentang kemerdekaan Sudan. Taha dan kaum intelektual lain yang setuju dengan kritiknya kemudian mendirikan Partai Republikan (al-Hizb alJumhü $\bar{r}$ ) pada Oktober 1945 untuk memperjuangkan kemerdekaan penuh dari Inggris dan Mesir. Publikasi pertama dan pamflet yang merefleksikan sebuah orientasi Islam modernis yang kuat, belum sepenuhnya terbangun kala itu. Kebijakan partai untuk berkonfrontasi langsung dengan otoritas kolonial membuat dirinya dan kawan-kawan ditangkap dan dipenjara pada tahun 1946. Kala itu, Țaha menjadi politikus Sudan pertama yang dipenjara otoritas kolonial Inggris. Namun, menanggapi berbagai tuntutan dari Partai Republikan, Gubernur Jenderal Inggris akhirnya melepaskannya setelah lima puluh hari di penjara. Hanya ia tidak lama hidup bebas. Pada 
tahun yang sama, ia kembali ditangkap dan divonis dua tahun penjara karena perannya atas apa yang disebut insiden Rufa'h (Ṭaha, 1987: 3-4).

Setelah keluar dari pabrik air dan listik di Khartoum, Țaha memilih berwiraswasta sebagai seorang engineer pada pertengahan tahun 1950-an. Pada akhir "persembunyiannya" itu, Oktober 1951, Țaha muncul dengan sebuah visi yang komprehensif berupa apa yang kemudian ia sebut dengan Second Message of Islam. Sekedar untuk diketahui, Sudan merdeka dari Inggris pada Bulan Januari 1956. Țaha terus menyebarkan pemikirannya itu lewat kuliah, newspaper, artikel, buku, dan lain-lain hingga akhir hayatnya Januari 1985. Pasca kudeta militer oleh Ja'far al-Numaery pada Bulan Mei 1969, Partai Republikan yang didirikannya kemudian berubah dari partai politik menjadi sebuah organisasi bernama Repubican Brothers (al-Ikhwān al-Jumhüriyyün) yang menyebarluaskan visinya itu. Kawankawannya yang masih menginginkan peran politis yang lebih sekular keluar menuju ke partai-partai lain. Sementara bagi mereka yang masih bersama Țaha, partai itu berubah menjadi semacam lingkungan spiritual di bawah bimbingan Țaha. Republican Brothers kemudian menjadi musuh yang diakui terus terang oleh al-Ikhwän al-Muslimūn, sebuah gerakan islamis noefundamentalis yang didirikan di Mesir. Al-Ikhwān al-Muslimūn ingin membangun sebuah aturan yang totalitarian sebagaimana kejayaan teokrasi abad tengah, sebaliknya Țaha percaya kepada demokrasi, parlementer maupun presidensil, dan sosialisme Fabian (Khalid Duran, 1992: 453- 467).

Pada tahun 1955, setahun sebelum kemerdekaan Sudan, Taha menerbitkan karyanya yang berjudul Usus Dustūr al-Südān, buku tersebut berisi idenya tentang konstitusi bagi Negara Sudan. Di dalam buku itu, ia mengungkapkan:

1. Bentuk negara yang sesuai bagi Sudan adalah pemerintahan federal, demokratis, sistem presidensil dan republik yang berasaskan sosialisme.

2. Menentang berbagai usaha yang dilakukan dalam rangka memformalkan hukum Islam (shari'ah). Pemberlakukaan shari'ah secara resmi sebagai hukum negara justru akan memancing pertikaian antar etnis dan agama di Sudan, terutama bagi kelompok non muslim dan warga Sudan keturunan non Arab. 
Tidak lama setelah kemerdekaan Sudan Bulan Januari 1956, sebuah komite dibentuk untuk penyusunan konstitusi yang akan diajukan ke depan Dewan Legislatif Nasional Sudan. Taha mewakili Partai Republik dalam komite tersebut, namun karena berselisih paham dengan penguasa eksekutif, ia keluar dari komite itu. Akhirnya komite itu memformalkan sharíah ke dalam konstitusi, karena memang dikehendaki mayoritas anggota, terutama dari partai yang, menurutnya, bersifat tradisionalis dan sektarian.

Namun sebelum rancangan tersebut dibawa ke hadapan dewan, terjadi kudeta militer berdarah pada Bulan Nopember 1958. Semua partai politik termasuk Partai Republik dibubarkan. Di bawah kepemimpinannya, Jenderal Abbud berkuasa secara mutlak. Țaha mencoba mendekati Jendral Abbud dan menawarkan ide Partai Republik lengkap beserta rancangan konstitusi, namun ditolak. Selama dua tahun pertama masa Regim Militer itu, Țaha mengambil inisiasi propaganda guna penyebaran ide-idenya di depan umum. Namun ide progresifnya dianggap sangat tidak toleran terhadap kaum tradisional keagamaan sehingga tiga orang mahasiswa dari gerakan Republik dikeluarkan dari Islamic Institute of Omdurman karena dianggap telah menyebarkan ajaran Ṭahaisme. Setelah peristiwa itu, Țaha dilarang berbicara di depan umum. Akitivitas Țaha dan pendukungnya itu beralih ke rumah-rumah pengikutnya.

Taha menolak akses ke media massa ketika mencoba melakukan pembelaan atas segala keyakinannya, namun dia melakukannya dengan menerbitkan bukunya yang diberi judul The Islam pada tahun 1960. Setelah Sudan kembali ke sistem parlementer multi partai, Ṭaha menggunakan Partai Republiknya untuk mempropagandakan ide-idenya tentang reformasi sosial, politik, dan agama, melalui kuliah umum, artikel di surat kabar dan buku. Pada tahun 1966-1967, dia menerbitkan tiga buku: Țariq Muhammad atau Mohamed's Path; Risālah Al-Salāh atau The Message of Prayer; dan al-Risālah al-Thäniyah min al-Isläm atau The Second Message of Islam. Ia juga orang pertama yang merancang dialog langsung guna menciptakan perdamaian di antara negara-negara Arab dengan Israel setelah perang 6 hari tahun 1967. Ia mengungkapkan persoalan Arab-Israel tersebut di dalam bukunya Mushkilat al-Sharq al-Awsat atau The Middle East Problem, dan Al-Tahạaddi al-ladhi Yu'aghih al-'Arab atau The Challenge 
Facing the Arabs. Kedua buku tersebut diterbitkan tahun 1967. TTaha amat menentang nasionalisme Arab di bawah kepemimpinan Gamal Abdul Nasser. Sama seperti ia menentang penerapan shari'ah secara primitif di Saudi Arabia, dan gerakan al-Ikhwān al-Muslimūn di berbagai negara Arab.

Partai tradisionalis sektarian bersama-sama dengan gerakan alIkhwān al-Muslimūn berkoalisi untuk mengesahkan pasal 5 ayat 2 di dalam konstitusi yang melarang kelompok komunis masuk ke dalam parlemen pada tahun 1965. Taha menentang pembubaran Sudanese Communist Party sebab ia menganggap keberadaan partai itu di dalam parlemen merupakan langkah awal penegakan demokratisasi di Sudan. Pada bulan Nopember 1968, ia dituduh murtad dan dituntut hukuman mati. Țaha menolak untuk datang di persidangan sesuai dengan prinsip hak konstitusionalnya untuk berekspresi dan mengemukakan pendapat. Namun Pengadilan Tinggi Sharíah di Khartoum memutuskan tetap menyidangkan perkaranya. Selain dituduh murtad, partai Republik, Ṭahaisme beserta gerakannya dianggap sebagai partai terlarang (Khalid Duran, 2009: 417).

Țaha terus menulis dan menyebarkan tulisannya hingga akhir rezim Numeiry mengutuk seluruh tulisan dan kuliahnya pada awal tahun 1970-an. Sisa-sisa hidupnya kemudian ia jalani dengan memberikan bimbingan terhadap kelompok yang kemudian dikenal sebagai the Republikan Brothers itu, dengan pengikut perempuannya yang terus bertambah. Dari sini, Țaha membangun sebuah komunitas yang sedapat mungkin menerapkan ajarannya tentang Islam. Sebagai komunitas kecil di dalam masyarakat Sudan yang besar, Republican Brothers memang tidak mampu berbuat banyak kecuali dalam komunitas kecilnya sendiri. Sebagai contoh, mereka menerapkan kesetaraan antara laki-laki dan perempuan tanpa diskriminasi seks dan lain-lain. Republikan juga merevolusi praktikpraktik pernikahan dalam batasan-batasan sharíah tanpa menyerang adat masyarakat yang masih berlaku. Namun, meski aktifitas mereka selalu dalam koridor hukum, pandangan mereka cenderung membangun oposisi terhadap lingkaran politik dan agama yang tradisional dan fundamental kala itu (An-Na'im: 7).

Hanya setelah sharíah dipaksakan untuk berlaku oleh dekret presiden mulai Agustus 1983, dan karenanya ia merusak kesatuan nasional antara Muslim utara dan non-Muslim selatan, kemudian mengarah 
kepada kebijakan represif dan kasar, Republikan mulai mendeklarasikan oposisinya. Penyebab nyata penangkapannya pada pertengahan 1983 adalah pamflet yang diisukan Republikan, yang mengkritik apa yang mereka anggap sebagai kegagalan pemimpin keamanan negara, juga apa yang terjadi bagi wakil presiden ketika dihasut oleh muslim fundamentalis untuk membenci atas nama agama dan melakukan kekerasan terhadap pengikut Republikan dan non-Muslim Sudan. Karena sejak dulu, bagi Republikan, memang harus ada reformasi radikal terhadap shari'ah agar dapat diterapkan di dunia modern. Republikan berkampanye kemanamana, meski pemimpin-pemimpin mereka ditangkap. Tidak ketahui mengapa akhirnya semua pemimpin Republikan itu dilepas kembali pada 19 Desember 1984, setelah kira-kira sembilan belas bulan dalam penangkapan tanpa dakwaan yang jelas. Namun pelepasan itu justu permulaan tahap paling fatal yang berujung pada peristiwa puncak yaitu eksekusi mati Ṭaha beberapa minggu kemudian (Ibid: 10).

Sumber lain mengatakan bahwa Țaha adalah figur kharismatik. Ia mirip dengan Gandi dan seorang uskup yang dicintai banyak orang di Brazil, Dom Helder Camara. Bahkan Presiden Numeiry, diktator yang kelak membunuhnya, pernah menyanjungnya sebagai "a man of great moral caliber with a healthy influence on Sudanese youth". Ia diterima banyak kalangan dengan berbagai strata sosial yang berbeda. Murid-murid memanggilnya "ustad". Pada saat tertentu, kemudian Numeiry cemburu atas nama popularitas TTaha yang terus melejit. Pada permulaan tahun 1983, Syaikh Muti'i, seorang fanatik dari Mesir, mendapat perlindungan di Sudan dari wakil presiden, Umar at-Tayyib, dan mulai menghasut orangorang muslim Sudan untuk melawan orang-orang Kristen yang sebangsa. Lewat telivisi milik pemerintah, ia mengajak untuk melawan Kristen dan menuntun agar Republican Brothers dianggap sebagai murtad dan dihukumi dosa besar, sebagaimana dikatakan hukum sharíah tradisional (Khalid Duran, 1992: 453-467).

Sementara Ṭaha sadar bahwa dirinya dan kawan-kawan dilepas hanya untuk dikejar oleh hukum baru itu, ia juga bertanggungjawab atas kampanye melawan kebijakan islamisasi Presiden Numeiry. Masih dalam satu minggu pelepasannya, pamflet disebar untuk menuntut pencabutan hukum baru atau yang disebutnya "September Laws". Ia juga menuntut 
sebuah garansi kebebasan demokrasi sipil termasuk untuk memperdebatkan prinsip dan proses kebijakan islamisasinya (An-Na'im:10).

Tepatnya Hari Rabu, 2 Januari 1985, empat pemimpin Republikan yang ditangkap di Omdurman dibawa ke pengadilan khusus pidana yang dibangun di bawah Judiciary Act 1984. Proses persidangan ditunda karena kasus serius itu memerlukan sanksi spesial dari presiden. Pada Hari Sabtu sore, 5 Januari 1985 Țaha ditangkap di rumahnya di Omdurman dan didakwa atas kesalahan yang sama. Pada Hari Senin pagi tanggal 7 Januari 985, Țaha dan empat pemimpin original republikan di bawa ke pengadilan khusus kriminal setelah sanksi dari pengadilan itu didapatkan dari presiden. Keputusan pengadilan khusus telah diputuskan pada Hari Selasa 15 Januari 1985. Presiden Numeiry menyatakan konfimasinya secara umum pada Hari Kamis 17 Januari 1985 di televisi pemerintah bahwa Ṭaha dijatuhi hukuman mati karena telah murtad, menyebarkan keimanan yang bersifat subversif, bahkan mengaku menjadi Tuhan. Keesokan harinya, Ṭaha langung dieksekusi, tepatnya Hari Jum’at pagi tanggal 18 Januari 1985 (Khalid Duran,1992: 453-467).

Terhadap empat anggota Republikan yang lain, Presiden Numeiry juga menyatakan bahwa mereka hanya mempunyai waktu dua hari untuk bertobat menyesali dan mengaku salah, atau dieksekusi pada Hari Minggu tanggal 20 Januari 1985. Begitu T. aha dieksekusi, empat orang itu menyatakan keinginannya untuk bertobat dan kemudian diampuni dan dibebaskan pada Hari Sabtu 19 Januari 1985 (An-Na'im: 16).

Dengan menyetujui pembukaan organisasi mereka dan menahan diri dari penyebaran lebih lanjut pandangan-pandangan Ṭaha, sekitar empat ratus orang seluruh anggota Republikan, laki-laki dan perempuan, yang ditangkap di Omdurman pada malam eksekusi dilepas kembali pekan itu. Setelah eksekusi Taha, pemikiran-pemikiran kritis menjadi berhenti, gerakan-gerakan juga mati.

Hanya saja, Presiden Numeiry tidak cukup lama bertahan dalam kekuasaannya. Ia segera menuai kecaman atas kampanye bengisnya melawan kelompok Republikan. Seluruh dunia Arab, bahkan lebih luas lagi, memprotesnya. Perang melawan rezim kemudian menemukan momentum dan berhasil menurunkan gelombang revolusi rakyat yang bahkan dibela militer dan pegawai negeri. Numeiry kemudian berhasil 
digulingkan dan dikudeta pada tanggal 6 April 1985, tujuh puluh enam hari setelah membunuh Țaha.

Sebagaimana diketahui, Presiden Numeiry memberikan konfirmasi lewat radio nasional dan televisi pada Hari Kamis sore tanggal 17 Januari bahwa seluruh kekuatan pengamanan telah disiagakan di pusat kota. Ketika polisi dan personel keamanan negara mengepung kelompok Republikan untuk penangkapan tanpa dakwaan, kekuatan tentara mengambil alih pengamanan di dalam dan sekitar penjara Khartoum Utara, di mana TTaha akan dieksekusi keesokan harinya. Pasukan payung dipindahkan ke dalam penjara dan sebuah helikopter sudah disiapkan sepanjang malam untuk membawa jenazah pasca eksekusi. Pada Hari Jum'at itu, operasi pengamanan terbesar yang disiagakan di penjara sudah siap. Petugas memeriksa identitas ratusan orang yang datang untuk melihat eksekusi publik yang dijadwalkan pukul sepuluh hari itu (Ibid: 17).

Ketika Ṭaha dibawa ke atas tangga tiang gantungan baja, kerudung yang menutup muka dibuka beberapa menit. Ia dilaporkan telah melihat kerumunan dengan sebuah senyuman sebelum kerudung itu dibuang kemudian untuk eksekusi yang sesungguhnya (New York Time, 1985: 2). Setelah eksekusi gantung dijalankan, jenazah dibawa turun, diletakkan di atas sebuah usungan, dan dibungkus dalam sebuah selimut tua. Kemudian dibawa ke helicopter dan terbang ke tujuan yang tidak diketahui. Belakangan dilaporkan bahwa jenazah dibakar dalam sebuah lubang dangkal di sebuah tempat di padang pasir barat Kota Omdurman. Hingga hari ini masih diragukan apakah orang yang membawanya pada operasi itu dapat mengidentifikasi di mana jenazah ditinggalkan kala itu.

Setelah digulingkannya Numeiry dan diundangkannya sebuah konstitusi transisional baru pada Oktober 1985, sebuah penyesuaian konstitusional telah diusulkan oleh putri tertua Țaha, Asma, bersama satu dari sekian anggota Republikan yang dihukum bersamanya pada Bulan Januari 1985. Mereka mengajukan petisi ke Mahkamah Agung Sudan untuk meninjau hukuman itu. Jaksa Agung pemerintah transisional membuat pernyataan lisan di depan Mahkamah Agung bahwa putusan Januari 1985 itu sepenuhnya tidak sah dan bahwa ia tidak mempunyai sesuatu untuk dikatakan dalam membela hukuman itu (al-Ayyam,1986). Namun Mahkamah Agung tetap ditanya respons tertulisnya terhadap 
petisi itu. Setelah mempertimbangkan semua bukti yang ada, akhirnya Mahkamah Agung memutuskan bahwa hukuman dan eksekusi Țaha itu sesungguhnya tidak sah.

Intinya, menurut an-Naim, tidak ada ketakutan untuk menolak Presiden Numeiry yang terlihat seperti pecinta damai tidak bersenjata itu. Situasi telah berubah dan memaksa adanya sebuah surat kabar yang memuat satu halaman penuh kritik terhadap kebijakan pemerintah tentang adanya konspirasi untuk membunuh Țaha. Hal ini dibuktikan berdasarkan korespondensi antara Presiden Numeiry dengan penasehat hukum utamanya untuk menangkap Ṭaha pada tanggal 5 Januari 1985.

Sebaliknya, an-Na'im memuji bahwa ada kebanggaan yang dapat dikatakan setelah Ṭaha menemui nasibnya. Aspek ini lebih penting karena telah memperlihatkan ujian paling tinggi terhadap salah satu ajaran inti pemikiran agama Taha, yaitu doktrin tentang submission to the will of God (menyatu dalam kehendak Tuhan). Sepanjang hidupnya, Taha mengajarkan bahwa submission to the will of God adalah esensi Islam. Taha selalu berupaya untuk dapat mencapai semacam kesatuan dalam segala aspek dalam kehidupan pribadi dan publiknya. Ia selalu mengatakan kepada murid-muridnya untuk melihat Tangan Aktor Original, yaitu Tuhan, di balik aktor atau sebab yang terlihat dalam setiap kesempatan dan peristiwa. Dengan menerima nasibnya itu, Taha menunjukkan bahwa keyakinan dan aksi dapat berkombinasi dalam kehidupan manusia dalam sebuah pola teladan yang konsisten dan tunggal, termasuk ujian puncak berupa kematian. Bagi banyak orang Sudan, dan mungkin bagi dunia keseluruhan, ketika kehidupan dan karyanya diapresiasi secara penuh, peristiwa Jum'at kelabu itu adalah saksi bicara betapa tinggi dan luarbiasanya moralitas Ṭaha itu (An-Na'im, 19).

\section{Pokok-Pokok Pemikiran Islam Mahmoud Mohamed Taha}

Țaha adalah seorang pemikir komplek yang pendekatannya merupakan ramuan antara filsafat politik, spiritual Islam, dan ketrampilan. Oleh Mohamed A. Mahmoed dalam bukunya, Quest for Divinity, A Critical Examination of the Thought of Mahmoud Muhammad Țaha, dikatakan:

"Ṭaha was first and foremost a mystical thinker who viewed individual and collective human action in term of a 'salvific determinism'; human life is 
intrinsically oriented toward God; it is only through God that humans can de-alienate themselves and realize their freedom, ultimate fulfilment and salvation". (Mahmoed, 2007: xii)

Masih menurut Mohamed A. Mahmoed, kontribusi penting TTaha dalam kajian keislaman adalah apa yang ditemukan dalam karyanya, The Second Message of Islam. Kata Mahmoud:

"Taha's Second Message of Islam is in effect a paradigmatic shift. The traditional Islamic paradigm that privileges the prophetic moment that is seen as the culmination of human salvation history is rejected in favor of paradigm that privileges a future moment. The golden age does not lie in the past but rather the future, when the second message is fully realized and when the earth will be filled equality and justice as it has been filled with inequity and injustice, and peace will prevail among all creatures". (Ibid: 178)

Teori-teori Țaha selain berpijak atas al-Qur'an dan al-Sunnah, juga berpijak atas pemikiran Barat, khususnya Marxism dan Socialism. Satu dari sekian pengaruh paling jelas pemikiran Barat terhadap pemikiran TTaha adalah teori evolusinya itu. Masih kata Mamoed:

"Both his theory of prayer and his theory of the second message of Islam rest on an evolutionary assumption and scheme. In the case of prayer, the evolutionary process takes the form of an upward movement from collective spirituality to individual spirituality, from imitation to authenticity, from fragmentation to unity, from mediated communication to direct communication. Likewise, evolutionary logic is central in the formulation of the second message theory that conceives human history in terms of progressive, spiral, upward movement from simplicity to complexity, from lower civilization rungs to higher ones, from social conflict to social harmony, from the society of 'believers' to society of 'Muslims." (Ibid: 179)

Terakhir, Mahmoed menyimpulkan bahwa: "His mystical vision and his reform project remain among the boldest and most original responses to the crisis of Islam in the modern world" (Ibid: 222).

Taha berhasil meyakinkan banyak orang Islam bahwa masih ada Islam di samping hukuman dan diskriminasi yang keras dan kurang berprikemanusiaan terhadap perempuan dan non-Muslim. Dalam sejarah hidup dan karyanya, Islam dapat menawarkan pengikutnya sebuah pandangan dunia yang cerdas dan dinamis yang dapat mengakomodasi dan mempromosikan semangat moral, intelektual dan seni masyarakat modern secara penuh. Pemikirannya tentang Second Message selain penting bagi umat Islam seluruh dunia, juga telah memicu perdebatan global 
yang belum selesai khususnya tentang isu-isu moral dan ideologi yang diusungnya (An-Na'im: 2).

Menurut Khalid Duran, dapat dikatakan bahwa inti pemikiran Taha berakar pada tiga hal: pertama, mistik dan konsep evolusi sejarah; kedua, Islam periode Makkah menggantikan Islam periode Madinah; dan ketiga, reformasi perempuan dan minoritas (Khalid Duran,1992: 453-467).

Peneliti mencoba menyimpulkan pandangan Țaha yang tersebar dalam bukunya, The Second Message, dalam bentuk piramida. Di puncaknya ada Tuhan yang tak terbatas, sementara di dasarnya ada kemanusiaan. Di masa lalu, agama telah direndahkan dari puncaknya menuju level kebutuhan dan kemampuan manusia dalam bentuk sharíah. Sedang puncak piramida itu akan selamanya melampaui jangkauan kita. Sebagai individu, setiap orang akan mengembangkan pemahamannya tentang agama, lewat pengetahuan akan dunia material dan akan dirinya sendiri. Hal ini sebagaimana firman Allah dalam al-Qur'an, 41 (Fuș̣ilat): 53,

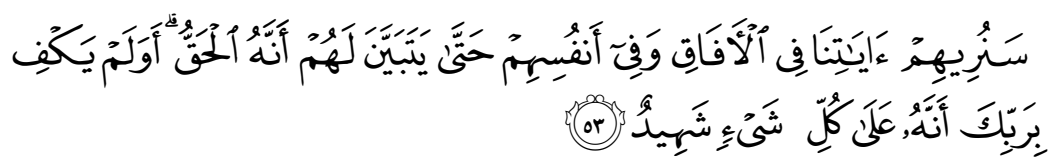

Dengan kata lain, Ia selalu mengatakan DiriNya kepada ciptaanNya hingga mereka mengetahuiNya. Dialah satu-satunya yang mengajar kita. Berbagai pengetahuan tambahan dalam kenyataannya adalah pendakian lebih tinggi dari dasar piramida Islam itu naik ke puncaknya dalam evolusi yang terus menerus. Sebagaimana seseorang mengembangkan pengetahuannya tentang agama, sesungguhnya ia meningkatkan sharíahnya sejalan dengan kebutuhan dan kemampuannya. Ia selalu menyuling dan memurnikannya.

Kemajuan individual dalam memahami agama kemudian menjadi shari'ah fardiyyah, hukum individual mereka. Sementara masyarakat menjadi berkembang sebagai sebuah hasil dari perkembangan individu. Shari'ah mereka juga menjadi lebih tersuling dan manusiawi. Hal ini menandakan sebuah gerakan ke arah yang lebih tinggi dari piramida di mana dasarnya adalah sharíah pesan pertama itu. 
Meski pesan pertama tidak demokratis, ia mendekati demokrasi di saat masyarakat secara keseluruhan belum siap akan demokrasi yang sebenarnya. Meski pesan pertama tidak sosialis, ia sesunggunya lebih dekat ke sosialisme pada saat masyarakat belum siap akan sosialisme ilmiah yang sebenarnya. Karena kemanusiaan telah berkembang lebih dari empat belas abad (era pesan pertama sharíah) ke arah kedewasaan, lewat karunia Tuhan menjadi mampu secara intelektual untuk menerapkan baik demokrasi maupun sosialisme, Islam harus disebarkan dalam term-term ini. Hal ini menandakan sebuah perkembangan dari dasar shari'ah pesan pertama yang lebih primitif menuju level yang kurang primitif, semacam mendekati puncak. Sementara puncaknya masih dan selalu berada alam individualitas tertinggi. Permulaan dasar islami yang baru adalah pintu gerbang sosialisme, dengan melarang adanya kepemilikan pribadi akan alat dan sumber-sumber produksi oleh satu orang atau sedikit orang dalam asosiasi. Ini membuka pintu legislasi islami ke arah sosialisme. Permulaan dasar islami yang juga baru adalah pintu gerbang demokrasi. Di sini, hak untuk bersuara dijaga dan diberikan seluas-seluaskan kepada setiap warga negara dalam usia tertentu, laki-laki atau perempuan, sebagaimana juga hak untuk dipilih dalam pemilu. Hal ini membuka pintu legislasi islami ke arah demokrasi.

Proses ini disebut tatwir al-tashīi (evolution of the law) yang menandai pentingnya perkembangan dari teks al-Qur'an cabang ke arah teks original. Ini adalah sebuah pergeseran dari satu teks ke teks-teks yang lain dalam al-Qur'an.

Ada sebuah area tumpah tindih antara pesan pertama dan second message, misalnya praktik ibadah di mana tidak ada evolusi kecuali ketika ia telah masuk ke alam sharíah fardiyyah atau sharíah individual. Setiap individu dapat tumbuh berkat karunia Tuhan dan dengan pengikutan sempurna kepada nabi hingga ia akhirnya berhasil sampai kepada individualitasnya sendiri, yang sesungguhnya berbeda dari manusiamanusia yang lain.

Shari'ah fardiyyah atau individual, bukan sharíah komunitas, adalah prinsip original Islam, sebagaimana individu, bukan masyarakat, yang menjadi tujuan akhir Islam. Tetapi orang-orang sudah tumbuh terbiasa untuk hidup dalam masyarakat, dan menjadi bingung juga takut 
ketika seseorang berbicara kepada mereka tentang shari'ah fardiyyah. Lebih dari itu, sharíah fardiyyah menandakan sebuah tangga kedewasaan dan tanggungjawab, di mana kebanyakan manusia masih kekanak-kanakan dan tidak bertanggungjawab, serta menginginkan orang lain mengerti tingkat tanggungjawabnya.

Ambang pintu second message adalah Pesan Pertama, kecuali aspek-aspek sharíah yang memang mengalami evolusi. Tidak ada evolusi dalam ibadah, kecuali zakat, yang sebelumnya dijadikan salah satu rukun Islam hanya karena orang-orang pada waktu itu tidak mampu berbuat lebih baik. Di sisi lain, rukun Islam yang sebenarnya adalah zakat yang sesuai dengan standar Nabi, karena zakat adalah prinsip original yang berdasar atas sumber utama yang pasti. Akan ada evolusi dalam dunia muamalat, termasuk hak asasi individual, dan struktur ekonomi dan politik. Semua materi yang berkaitan dengan perubahan sosial harus berkembang bersama masyarakat dan memamerkan vitalitas yang mendesak bagi pertumbuhan dan pembaharuan.

Prinsip original Second Message adalah vitalitas, perkembangan, dan pembaharuan. Seorang hamba/sālik yang cerdas yang sedang meningkat menuju second message harus berupaya memperbaharui kehidupan intelektual dan emosional setiap saat, sepanjang hari dan malam. Idealitasnya adalah Tuhan yang mendeskripsikan diriNya dalam al-Qứan, 55 (al-Raḥmān): 29,

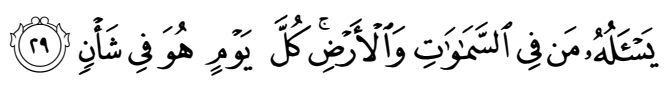

Pertama kali, seseorang menyatakan keimanannya dengan dua kalimat tauhid dan kemudian mengikuti sepenuhnya sunnah Nabi agar dapat sampai pada keyakinan yang sebenarnya bahwa tiada tuhan selain Allah. Pengikutan lebih lanjut dan lebih sempurna kepada Nabi akan mengantarkan seseorang untuk dapat merealisasikan bahwa keimanan tertinggi hanya berupa pernyataan sepenuhnya sebagaimana firman Allah dalam QS. 3 (Ali Imrān):18,

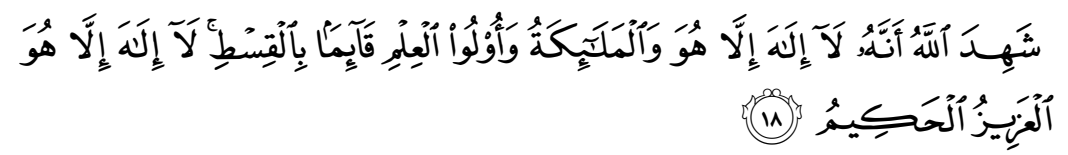


Pada titik ini, posisi individu akan berada dalam penghambaan dan berhadapan langsung dengan Tuhan tanpa perantara apapun, dan kemudian dikatakan dalam QS. 6 (al-Anām): 91,

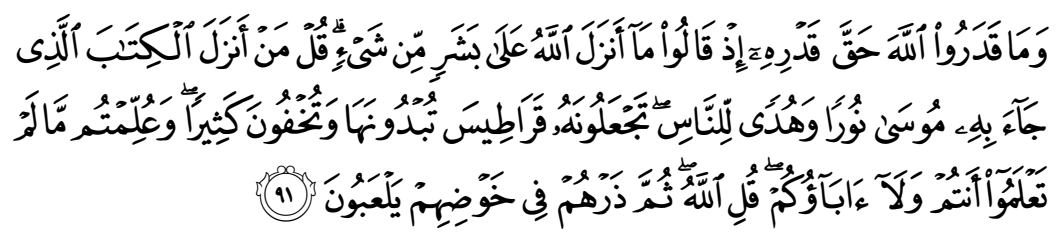

Kata-kata "Say God" berarti "menjadi Tuhan" (dalam arti memperoleh sebuah kesamaan dengan kualitasNya). Ini adalah ranah shari'ah fardiyyah atau hukum individual.

Ketika seseorang naik tangga second message, melewati first message, sesungguhnya ia sudah akan melewati tujuh langkah tangga itu: dari istām

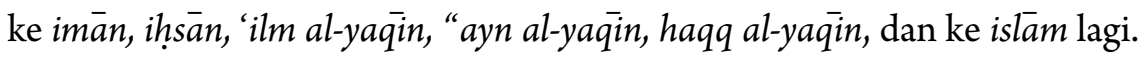
Kemudian ia mulai lagi dari sebuah level baru kepada sebuah siklus baru, dan seterusnya hingga tidak terbatas.

Islam adalah sebuah spiral. Permulaannya berupa hukum masyarakat dan penghujungnya berupa ketidakterbatasan bersama Tuhan. Setiap orang yang menapak menaiki tangga ini, ia menuju Tuhan dalam ketakterhinggaan. Jadi, setiap saat, ia selalu menambah pengetahuan dan menyerahkan dirinya, lagi dan lagi, kepada Tuhan. Semuanya akan memperbaharui kehidupuan intelektual dan emosionalnya. Masuk ke shariah fardiyyah sesungguhnya mendesak dan tidak sulit untuk dicapai. Tes kesempurnaan yang secara ekstrim tidak mencukupi, sesungguhnya berupa perasaan kebenaran bersama Tuhan dan memandang shari'ah fardiyyah sebagai bagian terpadu dengan kebenaran itu. Pernyataan ini tidaklah mungkin dicapai secara sempurna oleh sembarang individu, karena ia adalah proses yang tak terhingga dan tidak akan pernah berhenti.

Ini bukan pembicaraan yang idealistik, karena ia mempunyai titik praktik permulaannya, yang dengan kuat berada di dasar dan pada gilirannya mengantarkan seseorang naik ke arah iṭlāq, ketakterbatasan, pada berbagai capaian sesuai dengan pengetahuan masing-masing. Setiap orang sedang manapaki tangga ini, QS. 12 (Yüsuf): 76,

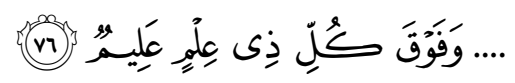


Ia kemudian sampai kepada pengetahuan puncaknya bersama Tuhan, QS. 9 (at-Tawbah): 78,

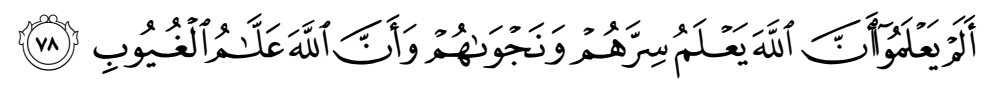

Hal ini berarti tidak ada batas kesempurnaan di mana seseorang dapat mencapainya. Tujuan manusia adalah naik ke sebuah level ketuhanan. Upaya ini hanya bisa berhasil jika berbasis pada pengabdian, praktik ibadah dan hubungan sosial dengan orang lain ('ibädah dan múamalah) sebagaimana dijelaskan di atas. Cukup bagi seseorang ketika Tuhan menginginkan dari diriNya semacam kesempurnaan, tidak ada mata yang mampu melihat, tidak ada telinga yang dapat mendengar, dan tidak terbersit dalam hati sekalipun.

Demikian sepintas pokok pikiran Țaha, yang peneliti sarikan dari bukunya, yang sebagiannya juga dikumandangkan an-Na'im di kemudian hari, di antaranya: teori evolusi dalam ajaran Islam; reformasi radikal sharíah (penggantian periode Madinah oleh periode Makkah); anti diskriminasi terhadap perempuan dan non-Muslim; konstitusionalisme; sekularisme; dan beberapa hal lain.

\section{Taha sebagai History of Idea an-Na'im}

Dalam kaca mata history of idea, pemikiran an-Na'im sesungguhnya mempunyai kesamaan dengan pemikiran Țaha, gurunya. Sebagaimana diketahui pemikiran an-Na'im tentang: harus ada syariah baru yang didasarkan pada naskh atau penghapusan ayat-ayat madaniyyah oleh ayatayat makiyyah yang menekankan kebebasan beragama, kesetaraan laki-laki dan perempuan, anti perbudakan, larangan penggunaan kekuatan terhadap negara lain, konstitusionalisme, dan sekularisasi, sesungguhnya ia ambil dari pemikiran Țaha dalam beberapa tulisannya. Naskh dari Second Message of Islam, konstitusionalisme dari Usus Dustur as-Sudan, dan sekularisme dari platform Partai Republikan.

Seorang John O. Voll misalnya, mengatakan bahwa an-Na'im telah mengembangkan kembali prinsip-prinsip umum Țaha ke dalam analisis kongkret tentang penerapan prinsip-prinsip itu dalam hukum publik Islam. Buku an-Na'im, Toward an Islamic Reformation, di mana ia secara cerdas mengenalkan Second Message of Islam, adalah sumber utama 
kritik pemikiran Republican dalam ranah aturan dan praktik syari`ah tentang keadilan kriminal, hak asasi manusia, dan hukum internasional (Voll: ix- xii).

Namun demikian, bukan berarti tidak ada perbedaan antara anNa im dan Ṭaha. Pemikiran Ṭaha dalam hal ibadah dan tasawuf sangat dan lebih berkembang dari pada dalam hal hukum publik dan pemerintahan. Inilah yang membedakan Țaha dengan an-Na'im, muridnya, yang sama sekali tidak menyinggung ibadah dan tasawuf, kecuali tentang pernikahan, itupun kalau fiqh nikah dimasukkan dalam kitāab al'ibäahah. Memang diketahui bahwa meskipun sebagai seorang pemimpin partai kecil, the Islamic Republican Party, yang gagal dalam pemilihan umum Sudan selama tahun 1950-an, Țaha juga masih sempat meletakkan dasar pendekatan baru dalam pemikiran Islam tentang hukum publik dan perkembangan sosial (Omdurman: tnp, 1974). Hal ini menunjukkan bahwa an-Na'im dan Ṭaha berbeda perhatian dalam hal ibadah, tasawuf, dan satu lagi yang tidak kalah menarik dan dengan yakin Țaha mengikutinya, yaitu sosialisme. Ide-ide TTaha memang sebuah sintesis yang komplek dari teori-teori evolusioner Barat (seperti Hegel dan Marx), mistisisme sufi, dan sumber-sumber hukum Islam, (al-Qur'an dan al-Sunnah). Tidak bisa dipungkiri bahwa Țaha terpengaruh oleh ide-ide evolusioner dialektis dalam beberapa hal (Avineri Shlomo dan Marx,1978). Ayat-ayat makiyyah yang menjunjung kesetaraan laki-laki dan perempuan dan kebebasan sipil dianggap Ṭaha sebagai versi dari evolusionisme sebagaimana dalam sosialisme (alMarxiyyah: 18).

An-Na'im tidak pernah mengusulkan sosialisme sama sekali. Sebagai alumni Inggris, ia juga tidak pernah menyebut-nyebut atau mengutip Marx, pemikir Sosialis Jerman itu.

Perbedaan perhatian antara Țaha yang lebih ke arah ibadah dan tasawuf di satu sisi dan an-Na'im yang lebih ke arah konstitusionalisme dan sekularisme di sisi lain, padahal sama-sama berangkat dari naskh, menurut peneliti, adalah akibat pendidikan Inggris an-Na'im. Sebagaimana diketahui, pada umumnya para pemikir Inggris memerintahkan suatu uraian yang lugas dan merasa curiga terhadap setiap pendekatan yang terlalu spekulatif. Mereka cenderung pada analisis, bukan sintesis. Suatu aliran filsafat Inggris yang khas adalah empirisme (John Lock dan David Hume, misalnya). 
Seperti tersirat dalam namanya, empirisme mementingkan pengalaman (kata Yunani empiria berarti "pengalaman indrawi"). Filusuf-filusuf Inggris mengutamakan hubungan antara filsafat dan ilmu pengetahuan. Pada umumnya, mereka bersifat anti metafisis. Sementara Țaha, tidak pernah mengeyam pendidikan di Inggris. Di negaranya sendiri, ia lebih tertarik pada pemikiran Jerman, karenanya perhatiannya lebih ke arah metafisik, tasawuf misalnya.

Satu hal yang barangkali tidak disadari banyak orang adalah bahwa konsep pemikiran pemberlakuan hukum Islam an-Na'im melalui apa yang disebutnya dengan public reason, sesungguhnya sama dengan konsep masyarakat moral milik Immanuel Kant, seorang filusuf Jerman. Sebagaimana diketahui, an-Na'im mengatakan bahwa norma-norma agama dapat dikonversi menjadi hukum negara, jika memang ditemukan alasan sekular untuk itu, atau dalam bahasa lain, jika norma-norma agama telah lolos dalam perdebatan nasional yang mengedepankan public reason. Padahal jauh-jauh sebelumnya, Kant sudah mengatakan bahwa ada public reason yang siap mengharmoniskan hubungan dua otoritas yang berbeda, akal dan wahyu. Ketika melihat agama, ia meyakini bahwa meski keduanya berbeda otoritas, sesungguhnya ada hubungan yang penting dan mendesak. Hubungan itu tidak selalu berupa konflik, bahkan fungsi akal publik ( $p u b l i c$ reason) yang layak harus memasukkan rujukan-rujukan wahyu. Yang ia maksud sebagai public reasoning adalah penalaran yang dilakukan tanpa batasan yang dipaksakan oleh berbagai otoritas lain sehingga memastikan universalitas akal (Phil Enns, 2007: 103-114).

Perkataan an-Na'im yang mengutip Joseph Schacht bahwa para ahli fiqh historis tidak membedakan hukum Islam menjadi privat dan publik, mereka hanya membedakannya menjadi hak Tuhan dan hak manusia (Ibid: 5), menurut peneliti, sesungguhnya juga merupakan bukti bahwa an-Na'im berbeda dengan Ṭaha karena Ṭaha masih memandang ḥudūd sebagai bagian dari hukum pidana yang masih relevan.

Selain kenyataan bahwa Taha sebagai history of idea bagi an-Na'im, sesungguhnya semakin jelas bahwa kekuatan yang mendasari sikap teoritis an-Na'im bukan semata merupakan sesuatu yang individual semata, yakni tidak berasal dari proses individu menyadari kepentingannya dalam arus pemikiran, akan tetapi lebih berasal dari tujuan-tujuan kolektif suatu kelompok yang mendasari pemikiran individu, dan dalam hal ini anNa'im hanyalah berpartisipasi dalam pandangan yang telah digariskan 
sebelumnya. Karenanya, dapat diketahui bahwa sebagian besar pemikiran tidak dapat dimengerti secara betul selama kaitannya dengan kehidupan atau dengan implikasi sosial kehidupan manusia tidak diperhitungkan. Karena itu, dapat dipahami bahwa latar belakang sosial ini muncul sebagai kekuatan yang tidak kelihatan yang mendasari pemikiran an-Na'im. Peneliti menyadari bahwa pemikiran an-Na'im bukanlah hasil ilham terisolasi dari dirinya sendiri sebagai pemikir. Pengalaman-pengalaman historis kolektif rakyat Sudan, atau khususnya pengikut Republikan yang diandaikan an-Na'im, namun tanpa syarat dianggap sebagai "pikiran kelompok", sesungguhnya mendasari tilikan mendalam an-Na im.

\section{Simpulan}

Sesungguhnya pemikiran an- Na'im mempunyai kesamaan dengan pemikiran Taha, gurunya. Pemikiran an-Na'im tentang: harus ada syariah baru yang didasarkan pada naskh atau penghapusan ayat-ayat madaniyyah oleh ayat-ayat makiyyah yang menekankan kebebasan beragama, kesetaraan laki-laki dan perempuan, anti perbudakan, larangan penggunaan kekuatan terhadap negara lain, konstitusionalisme, dan sekularisasi, sesungguhnya ia ambil dari pemikiran Țaha dalam beberapa tulisannya. Naskh dari Second Message of Islam, konstitusionalisme dari Usus Dustur as-Sudan, dan sekularisme dari platform Partai Republikan.

Namun demikian, bukan berarti tidak ada perbedaan antara anNa im dan Ṭaha. Pemikiran Ṭaha dalam hal ibadah dan tasawuf sangat dan lebih berkembang dari pada dalam hal hukum publik dan pemerintahan. Selain itu, Țaha lebih memilih sosialisme, sementara an-Na'im tidak.

Hanya satu hal yang barangkali tidak disadari banyak orang yaitu konsep pemikiran pemberlakuan hukum Islam an-Na'im melalui apa yang disebutnya dengan public reason. Hal dimaksud sesungguhnya sama dengan konsep masyarakat moral milik Immanuel Kant, seorang filusuf Jerman.

Pemikiran an-Na'im bukanlah hasil ilham terisolasi dari dirinya sendiri sebagai pemikir. Pengalaman-pengalaman historis kolektif rakyat Sudan, atau khususnya pengikut Republikan yang diandaikan an-Na'im, namun tanpa syarat dianggap sebagai "pikiran kelompok", sesungguhnya mendasari tilikan mendalam an-Na'im. 


\section{BIBLIOGRAFI}

\section{Buku:}

Avineri Shlomo, The Social and Political Thought of Karl Marx (Cambridge: Cambridge University Press, 1978)

Kuntowijoyo. Metodologi Sejarah. Yogyakarta: Tiara Wacana, 2003.

Lapidus, Ira M. Sejarah Sosial Umat Islam, Bagian III. Jakarta: Rajawali Press, 2000

Mahmoud Mohamed TTaha, The Second Message of Islam (New York: Syracuse University Press, 1987)

Mannheim, Karl. Ideologi dan Utopia: Menyingkap Kaitan Pikiran dan Politik, terj. F. Budi Hardiman. Yogyakarta: Kanisius, 1991.

Marx, "Contribution to the Critique of Hegel`s Philosophy of Right", dalam Tucker, Robert (ed.), The Marx-Engels Reader (New York: New York Press, 1978).

Mohamed A. Mahmoed, Quest for Divinity, A Critical Examination of the Thought of Mahmoud Muhammad Țaha (Syracuse: Syracuse University Press, 2007)

Na im (an), Abdullahi Ahmed. Dekonstruksi Syariah, terj. Ahmad Suaedy dan Amiruddin Arrani. Yogyakarta: LKiS, 1997. . Toward an Islamic Reformation, Civil Liberties, Human Rights and International Law. Syracuse: Syracuse University Press, 1990.

Quran dan Terjemahannya. Madinah Munawwarah: Mujamma' Khādim alHaramayn al-Sharifayn al-Malik Fahd, $1411 \mathrm{H}$.

\section{Jurnal:}

Khalid Duran, "An Alternatif to Islamism: The Evolutionary Thought of Mahmud Țaha”, Cross Currents, vol. 42 (Winter 1992); ProQuest Religion, 453-467.

Minlib Dallh, "Book Review: Quest for Divinity, A Critical Examination of the Thought of Mahmoud Muhammad Taha By Mohamed 
A. Mahmoud”, The Muslim World, vol. 99, no. 2 (April 2009); ProQuest Religion, 417-422.

Phil Enns, "Reason and Revelation: Kant and the Problem of Authority", Int J Philos Relig, 62 (2007), 103-114.

\section{Website:}

http://en.wikipedia.org/wiki/Mahmoud_Mohamed_Ṭaha\#cite_ref-0. Dikses 20 Desember 2014.

\section{Surat Kabar:}

Al-Ayyam, 18 April 1986.

New York Time 19 Januari 1985. 